\title{
PEMANFAATAN LIMBAH BOTOL PLASTIK MELALUI PELATIHAN WIRAUSAHA PRODUK AKSESORIS BAGI IBU RUMAH TANGGA
}

\author{
Shinta Doriza ${ }^{1)}$,Vera Utami Gede Putri ${ }^{2)}$ \\ Jurusan IKK Fakultas Teknik Universitas Negeri Jakarta \\ Kampus A UNJ Jalan Rawamangun Muka Jakarta Timur \\ shintadoriza@yahoo.com ${ }^{1)}$ \\ viadachlan@yahoo.com ${ }^{21}$
}

\begin{abstract}
ABSTRAK
Aksesori khususnya fashion adalah merupakan produk yang dibuat sebagai pelengkap pakaian agar terlihat lebih menarik.Seperti, kalung, anting, gelang, bando dan jepit rambut.Aksesoris dapat dibuat dengan menggunakan beraneka ragam jenis material.Salah satunya material plastik.

Pembuatan aksesoris dengan bahan plastik sangat mudah dibuat khususnya para ibu rumah tangga. Material plastik dapat diperoleh dengan memanfaatkan limbah botol plastik Pemanfaatan limbah botol air mineral bukanlah sekedar mencari keuntungan material saja melainkan sebagai bagian menjaga kelestarian lingkungan.

Pelatihan ini diharapkan menjadikan para ibu rumah tangga mampu menjadi wirausahawan yang dapat membuat produk aksesoris dengan memanfaatkan limbah botol plastik.Hasil aksesoris tersebut dapat di jual oleh mereka untuk menambah income keluarga untuk meningkatkan kesejahteraan keluarga khususnya dan meningkatkan peran serta perempuan dalam pembangunan.
\end{abstract}

Kata Kunci: Limbah Botol Plastik, Aksesoris, Wirausaha Ibu Rumah tangga

\section{PENDAHULUAN}

Penggunaan plastik di Indonesia tidak dibatasi. Plastik banyak digunakan untuk kebutuhan alat rumah tangga dan produksi, khususnya untuk kemasan makanan dan minuman. Sisa kemasan tersebut banyak dibuang begitu saja yang menyebabkan penumpukan limbah plastik semakin meningkat. Setiap pabrik menghasilkan rata-rata satu ton limbah plastik setiap minggunya di Jabodetabek. Jumlah tersebut akan terus bertambah, karena sifat dari pelastik antara lain tidak dapat membusuk, tidak terurai secara alami, tidak dapat menyerap air, maupun tidak dapat berkarat, dan pada akhirnya menjadi masalah bagi lingkungan (Yayasan Bina Pembangunan, 1986).
Limbah botol plastik masih dianggap sebagai sampah yang kurang bermanfaat. Padahal limbah botol plastik dapat dimanfaatkan menjadi beraneka ragam bentuk barang yang berguna yang dapat mempercantik ruang atau si pemakainya. Selain itu, barang tersebut bisa dijual agar mampu memberikan penghasilan tambahan bagi si pembuat. Khususnya, pemanfaatan limbah botol air mineral bukanlah sekedar mencari keuntungan material saja melainkan sebagai bagian menjaga kelestarian lingkungan. Seperti, ibu-ibu di Gresik Jawa Timur, limbah botol air mineral bisa di sulap menjadi aneka souvenir cantik berkualitas serta mampu memberikan penghasilan tambahan bagi mereka (Berita 86, 2010).

Salah satu upaya yang dilakukan oleh dunia fashion adalah membuat produkfashion 
ramah lingkungan yang dikenal sebagai ecofashion. Menurut Sustainable Technology Education Project (STEP) label eco-fashion pantas diberikan kepada produk mode yang ramah lingkungan, peduli akan kesehatan konsumen. Penggunaaan limbah botol plastik dalam pembutan produk fashion merupakan salah fashion yang diproduksi dan diciptakan dengan mempertimbangkan lingkungan melalui penggunaan bahan daur ulang yang pada awalnya tidak langsung berhubungan dengan fashion (Milchop, diunduh 1 April 2014). Dimana botol plastik yang sebelumnya berguna sebagai botol untuk tempat air mineral, setelah air mineral tersebut habis di konsumsi maka botol plastik air mineral tersebut dapat dipergunakan sebagai material bagi aplikasi salah satu produk fashion yaitu aksesoris.

Aksesoris merupakan pelengkap busana yang dapat mempermanis penampilan seseorang wanita. Produk aksesoris tersebut berupa anting, jepit rambut, kalung, dan bando.Pembuatan aksesoris dengan bahan plastik sangat mudah dibuat khususnya para ibu rumah tangga. Hal ini dikarenakan hasil aksesoris tersebut dapat di jual oleh mereka untuk menambah income keluarga untuk meningkatkan kesejahteraan keluarga khususnya dan meningkatkan peran serta perempuan dalam pembangunan.

Pelatihan ini merupakan program kewirausahaan yang dilakukan oleh Dosen UNJ dalam rangka Pengabdian pada Masyarakat. Pelatihan ini ditujukan terutama untuk masyarakat yang ingin berwirausaha. Khususnya para ibu rumah tangga di Kelurahan Cipinang Besar Utara. Melalui wirausaha produk aksesoris ini maka motivasi berwirausaha perempuan tersebut dapat meningkat untuk membiayai kehidupan keluarganya menuju keluarga sejahtera.

Rumusan masalah dari kegiatan ini: Bagaimana membuat produk aksesoris dengan memanfaatkan limbah botol plastik yang dilakukan oleh para ibu rumah tangga agar mempu menjadi wirausaha sehingga dapat menambah penghasilan keluarga dan masyarakat?
Setelah selesai mengikuti pelatihan ini diharapkan peserta mampu menjadi wirausahawan dengan membuat produk aksesoris dengan memanfaatkan limbah botol plastik yang berguna menambah penghasilan keluarga dan masyarakat.Harapan dari manfaat kegiatan ini adalah:

a. Ibu rumah tangga yang mandiri, sehat dan berdaya guna di tengah masyarakat

b. Mengembangkan jejaring kemitraan antara Lembaga Pengabdian Masyarakat UNJ dan Jurusan Ilmu Kesejahteraan Keluarga UNJ dengan Kelurahan Cipinang Besar Utara Jakarta Timur

\section{TINJAUAN PUSTAKA}

A. Pemanfaat Limbah Botol Plastik

Menurut kamus bahasa Indonesia pemanfaatan berasal dari kata manfaat. Manfaat adalah guna, faedah yang mendapat imbuhan pe dan akhiran an. Pemanfaatan adalah memanfaatkan barang yang sudah ada guna dijadikan produk lain sehingga meningkatkan daya guna produk.

Limbah, menurut kamus bahasa Indonesia, limbah adalah sisa proses produksi. Secara umum yang disebut limbah adalah bahan sisa yang dihasilkan dari suatu kegiatan dan proses produksi, baik pada skala rumah tangga, industri, pertambangan, dan sebagainya. Limbah adalah buangan yang dihasilkan dari suatu proses produksi baik industri maupun domestik (rumah tangga). Istilah lain limbah adalah sampah. Limbah adalah sisa proses produksi (Yuwono dan Abdullah, 1994:262).

Limbah juga merupakan suatu zat atau benda yang bersifat mencemari lingkungan dan tidak memiliki nilai ekonomis karena limbah tersebut dibuang (Abdurahman, 2008:102).Pada kota-kota besar di negara berkembang, limbah plastik merupakan permasalahan lama yang sering dihadapi terutama Indonesia.Hal ini dikarenakan tidak bisa hancur atau dapat hancur dengan memakan ratusan tahun.Limbah pun telah dinyatakan berbahaya oleh Badan Pengawas Obat dan Makanan (BPOM). Konstribusi plastik terhadap pencemaran 
lingkungan sangat besar termasuk juga terhadap pemanasan global. Zat-zat kimia yang terkandung dalam plastik dapat mencemari lingkungan sekitar saat proses penguraiannya dalam tanah.

Salah satu penanganan terhadap limbah adalah memanfaatkan limbah tersebut sehingga memiliki nilai ekonomis.Khususnya, limbah plastik yang bagi para pelaku bisnis atau pengusaha (entrepreneur) dapat dijadikan sebagai peluang yang dapat dikembangkan. Hal ini dibuktikan dengan munculnya beberapa industri baik skala kecil atau besar untuk mendaur ulang plastik baik secara langsung diproduksi ulang menjadi produk baru atau benar-benar didaur ulang menjadi bahan baku. Sudah pasti ini akan membawa dampak positif bagi lingkungan, selain itu industri daur ulang plastik tentu akan membuka lapangan kerja baru bagi masyarakat.

Salah satunya limbah plastik botol. Menurut Baedowy, usaha daur ulang botol plastik ini sangat mudah dijalankan siapa saja dan bisa menyerap tenaga kerja dari masyarakat bawah. Proses daur ulang botol plastik dimulai dengan penyediaan bahan baku berupa botolbotol plastik bekas yang biasanya didapat dari lapak atau pengepul. Harga sampah botol plastik bervariasi antara Rp.5000, Rp.7000 hingga diatas Rp.7000 per kilogramnya tergantung jenis botol plastiknya.

Limbah botol plastik ini digunakan untuk aksesoris pelengkap wanita. Limbah botol plastik dapat dikreasikan menjadi kerajinan tangan dalam bentuk beragam aksesoris. Dengan kata lain, limbah botol plastik tersebut tidak bisa disebut sebagai limbah atau sampah lagi. Pemanfaatan limbah botol air mineral bukanlah sekedar mencari keuntungan material saja melainkan sebagai bagian menjaga kelestarian lingkungan. Seperti, ibu-ibu di Gresik Jawa Timur, limbah botol air mineral bisa di sulap menjadi aneka souvenir cantik berkualitas serta mampu memberikan penghasilan tambahan bagi mereka (Berita 86).

Limbah botol plastik yang digunakan dalam produk aksesoris ini botol jenis Polyethylene Terephthalate (PET) dan High
Density Polyethylene (HDPE). Hal ini dikarenakan jenis botol ini merupakan kemasan yang hanya bisa digunakan sekali pakai.Jika isi kemasan ini sudah habis maka kemasan tidak dapat di isi ulang.Dengan demikian kemasan tersebut menjadi limbah dan dapat digunakan untuk pembuatan produk aksesoris ini.

\section{B. Wirausaha}

Wirausaha adalah orang yang kreatif dan inovatif serta mampu mewujudkannya untuk peningkatan kesejahteraan diri, masyarakat, dan lingkungannya (Lupiyoadi, 2004). Wirausaha yang berhasil adalah wirausaha yang mampu bertahan dengan segala keterbatasannya, memanfaatkan, dan meningkatkannya untuk memasarkan peluang dengan baik serta terus menciptakan reputasi yang membuat perusahaan itu bisa berkembang.

Karakteristik/sifat wirausaha menurut Sukardi (1991), sebagai berikut:

1. Sifat Instrumental; menunjukkan bahwa wirausaha dalam berbagai situasi selalu memanfaatkan segala sesuatu yang ada dilingkungannya untuk mencapai tujuan pribadi dalam berusaha.

2. Sifat Prestatif; menunjukkan bahwa wirausaha dalam berbagai situasi selalu tampil lebih baik, lebih efektif dibandingkan dengan hasil yang dicapai sebelumnya.

3. Sifat Keluwesan Bergaul; menunjukkan bahwa wirausaha selalu berusaha untuk cepat menyesuaikan diri dalam berbagai situasi hubungan antar manusia.

4. Sifat Kerja Keras; menunjukkan bahwa wirausaha selalu terlibat dalam situasi kerja, tidak mudah menyerah sebelum pekerjaan selesai.

5. Sifat Keyakinan Diri; menunjukkan bahwa wirausaha selalu percaya pada kemampuan diri, tidak ragu-ragu dalam bertindak bahkan memiliki kecendrungan untuk melibatkan diri secara langsung dalam berbagai situasi.

6. Sifat Pengambilan Resiko; menunjukkan bahwa wirausaha selalu memperhitungkan keberhasilan dan kegagalan dalam 
melaksanakan kegiatan dalam mencapai tujuan berusaha.

7. Sifat Sewa Kendali; menunjukkan bahwa wirausaha dalam meng-hadapi berbagai situasi selalu mengacu pada kekuatan dan kelemahan pribadi, batas-batas kemampuan dalam berusaha.

8. Sifat Inovatif; menunjukkan bahwa wirausaha selalu mendekati ber-bagai masalah dalam berusaha dengan cara-cara baru yang lebih bermanfaat.

9. Sifat Kemandirian; menunjukkan bahwa wirausaha selalu mengem-balikan perbuatannya sebagai tanggung jawab pribadi.

Berdasarkan karakteristik/sifat wirausaha ada juga faktor-faktor yang dapat memotivasi seseorang menjadi wirausaha. Guna mengetahui faktor-faktor tersebut maka seseorang harus memahami terlebih dahulu apa sebenanrnya yang orang lain butuhkan. Namun demikian, faktor-faktor yang dapat memotivasi seseorang berbeda antara satu dengan lainnya. Berikut faktor-faktor yang dapat memotivasi seseorang menjadi wirausaha sebagai berikut (Lupiyoadi, 2004).

1. The foreign refugee; adanya peluang ekonomi di negara lain yang lebih menguntungkan mendorong orang untuk meninggalkan negaranya sendiri untuk berwirausaha disana.

2. The corporate refugee; adanya ketidakpuasan seorang pekerja dengan lingkungan perusahaannya.

3. The parental refugee; adanya individu yang telah memperoleh pendidikan dan pengalaman bisnis yang dibangun keluarganya sejak masih kanak-kanak.

4. The feminist refugee; adanya deskriminatif yang diperoleh oleh para wanita baik dalam sistem pendidikan, lingkungan perusahaan maupun masyarakat, guna membuktikan bahwa mereka mampu mendirikan perusahaan seorang diri.

5. The housewife refugee; adanya perubahan peran ibu rumah tangga karena telah memiliki anak yang tidak balita lagi serta untuk membantu keuangan keluarganya.

6. The society refugee; adanya anggota masyarakat yang tidak setuju dengan kondisi lingkungan-nya biasanya akan mencoba menjalankan usaha yang tidak terikat dengan lingkungan yang ada.

7. The educational refugee; adanya kegagalan individu dalam studinya atau ketidak cocokan dengan sistem pendidikan yang ada telah membuat mereka terpacu untuk ber-wirausaha.

\section{Ibu Rumah Tangga}

Keluarga akan merupakan suatu unit terkecil dalam masyarakat yang bukan hanya berfungsi sosial budaya, tetapi juga berfungsi ekonomi. Keluarga merupakan wahana mencapai tujuan pembangunan. Hal ini menyebabkan keluarga perlu memper-siapkan diri dalam keterlibatannya sebagai agen pembangunan di sektor ekonomi produktif (Achir, 1994).

Ibu rumah tangga merupakan salah satu dari anggota yang ada di sebuah rumah tangga. Keterlibatan ibu rumah tangga sebenarnya bukan merupakan sebagai tulang punggung keluarga, tetapi mereka berhak juga mendapatkan penghasilan tambahan selain penghasilan yang diperoleh dari kepala keluarga. Hal ini tidak terlepas dari salah satu peran ibu sebagai pencari nafkah tambahan dalam keluarganya (Wikipedia, 2010). Penghasilan yang diperoleh para ibu rumah tangga tidak di peroleh dengan tiba-tiba tetapi diperoleh setelah mereka memperoleh ketrampilan yang dapat menambah penghasilan keluarga. Salah satunya adalah ketrampilan membuat aksesoris dengan memanfaatkan limbah dari botol plastik.

\section{Produk Aksesoris}

Aksesori adalah benda-benda pelengkap busana yang berfungsi sebagai hiasan untuk menambah keindahan pemakainya (Triyanto, 2012, h.6). Dalam Kamus Besar Bahasa Indonesia (KBBI), aksesori yaitu barang yang berfungsi sebagai pelengkap dan pemanis busana. Aksesori (atau aksesoris) adalah benda- 
benda yang tidak lepas bahkan selalu dikenakan seseorang khususnya wanita untuk mendukung atau menjadi pengganti pakaian (Yuki, 2005). Aksesoris berasal dari bahasa perancis yaitu "accecories" yang mempunyai arti "pelengkap", pengertian pelengkap disini adalah pelengkap busana. Pelengkap busana adalah kelompok benda-benda yang biasa dikenakan orang untuk melengkapi penampilannya atau melengkapi pakaian yang dikenakannya.

Aksesoris yaitu benda-benda yang menambah keindahan bagi pemakai, seperti pita rambut, sirkam, bando, jepit hias, penjepit dasi, kancing manset, giwang, anting, kalung dan liontin, gelang tangan, gelang kaki, jam tangan, kaca mata, cincin, bros, mahkota. Pelengkap busana yang berfungsi menambah keserasian berbusana disebut aksesori/aksesoris (bahasa Inggris: accessory, jamak menjadi accessories).

Aksesori khususnya fashion adalah merupakan produk yang dibuat sebagai pelengkap pakaian agar terlihat lebih menarik. Banyak sekali jenis aksesori fashion yang sangat bagus seperti tas tangan, topi, ikat pinggang, jam tangan, kacamata, pin, bando dan perhiasan (kalung, gelang, cincin dan anting-anting).

Pemakaian aksesoris bisa memberikan kenyamanan membuat sebagian orang lebih nyaman selain itu juga bisa melengkapi pakaian yang kita kenakan.Bagi orang yang peduli dengan fashion pastinya membutuhkan pertimbangan dalam memilih perhiasan atau aksesoris untuk mendapatkan citarasa yang baik dan lebih berkesan.Selain itu, berdasarkan bentuknya maka aksesoris juga dikaitkan dengan peran gender bagi pemakainya.

\section{Kalung}

Kalung merupakan salah satu aksesoris yang sering sekali digunakan oleh wanita serta dipakai melingkar dileher.Namun demikian, pada zaman sekarang ini banyak juga kaum lakilaki yang memakai kalung sebagai aksesoris.

Kalung biasanya dibuat dengan berantai dan sebagian besar disertakan bersama liontin. Kalung juga bisa dibuat secara bervariasi dari batu, berlian, mutiara, kristal, kerang, kayu, dengan bentuk dan ukuran yang berbeda.

\section{Gelang}

Gelang adalah salah satu perhiasan yang digunakan pada pergelangan tangan.Gelang pada dasarnya dibuat dengan bahan-bahan berantai atau karet juga bisa disertai dengan manik-manik. Gelang juga bisa dibuat secara bervariasi dari batu, berlian, mutiara, kristal, kerang, kayu, dengan bentuk dan ukuran yang berbeda.

\section{Anting}

Anting adalah perhiasan yang dipakai dengan cara ditindik di telinga. Istilah lain anting adalah giwang. Anting biasa dipakai oleh para wanita namun seiring berkembangnya zaman kini beberapa pria juga banyak yang memakai anting

Bentuk anting harus disesuaikan dengan ukuran lingkarnya. Ukuran lingkarnya tidak lebih dari $0,5 \mathrm{~cm}$. Jika diameternya yang terlalu besar, akan merepotkan.

Anting bisa dibuat dari batu, berlian, mutiara, kristal, kayu, dengan bentuk dan ukuran yang berbeda. Sekarang banyak sekali modelmodel anting baru yang bisa disesuaikan dengan pakaian dan bahkan tidak jarang satu model hanya dimiliki oleh satu orang.

\section{Bando}

Bando merupakan hiasan yang diletakkan dikepala.Bando biasa dipergunakan untuk mempercantik rambut.Bando bermanfaat menahan rambut dari wajah atau mata.

\section{Jepit Rambut}

Sama halnya dengan bando, jepit rambut merupakan hiasan yang diletakkan dikepala.Jempit rambut biasa dipergunakan untuk mempercantik rambut.

\section{BAHAN DAN METODE}

\section{A. Spesifikasi Bahan Yang Dipakai}

1. Bahan Utama

Bahan utama yang digunakan adalah limbah botol plastik dan bahan utama untuk aksesoris.Limbah botol plastik yang digunakan dalam produk aksesoris ini botol jenis 
Polyethylene Terephthalate (PET) dan High Density Polyethylene (HDPE).Jenis botol ini hanya bisa digunakan sekali pakai, artinya jika isi kemasan ini sudah habis maka kemasan tidak dapat di isi ulang sehingga menjadi limbah dan dapat digunakan untuk pembuatan produk aksesoris ini.

Karakteristik jenis botol plastik yang digunakan adalah botol plastik yang memiliki ketebalan lebih tebal daripada botol plastik khusus air mineral. Selain itu, botol plastik yang dipergunakan adalah botol plastik yang sudah ada warnanya (biru dan hijau). Hal ini dikarenakan untuk menghindari proses pewarnaan pada bahan utama.

Bahan utama untuk aksesoris, antara lain :

a) Bando untuk membuat bando dengan bahan plastik;

b) Anting (pengait anting) untuk membuat anting, kait anting yang digunakan adalah yang cantol dengan bahan logam;

c) Jepit rambut untuk membuat jepitan rambut; dan

d) Rantai untuk kalung. Berikut gambar.

\section{Bahan Penunjang}

Bahan penunjang yang digunakan, antara lain: kawat monel, pita grossgrain bermotif, kancing polong besar, kancing motif kecil, kain flanel, kain jala, dan jump ring.

\section{Alat}

Kegiatan ini menggunakan peralatan. Kegunaan masing-masing peralatan tersebut.

Pertama, Gunting untuk memotong dan merapihkan hasil potongan-potongan botol plastik.Kedua, Satu set tang yang terdiri dari,:

a) Tang cucut dengan bentuk unjung lancip. Tang ini berguna untuk merangkai atau mengatupkan rantai, ring, atau paku cantol dan paku mati yang terbuka;

b) Tang potong untuk memotong paku cantol dan paku mati; dan

c) Tang plintir untuk melengkung-kan kawat atau paku cantol atau paku mati. Ketiga, Lem uhu untu menyatukan potonganpotongan botol plastik menjadi bentuk yang cantik dan unik. Terakhir keempat,
Paku payung untuk membuat lubang pada potongan botol plastik.

\section{B. Subyek Kegiatan}

Subyek kegiatan ini adalah ibu-ibu rumah tangga yang belum memiliki pekerjaan tetap di Rukun Warga 10 Kelurahan Cipinang Besar Utara Jakarta Timur. Jumlah peserta 20 (dua puluh) orang. Setiap peserta diberikan materi teori, materi praktek berikut bahan praktek, dan hadiah.

Materi kegiatan meliputi teknik pembuatan 5 jenis aksesoris (bando, ris.anting, jepit rambut, gelang, dan kalung) dan pengenalan wirausaha aksesoris.Materi paktek yang diberikan sepeti bahan utama, bahan penunjang, dan peralatan. Seluruh materi praktek diberikan

\section{Metode Kegiatan}

Kegiatan ini merupakan kegiatan yang menghasilkan suatu produk maka metode yang digunakan adalah Pertama, 30\% teori berupa ceramah, disertai contoh-contoh dan diskusi kelompok. Kedua, $70 \%$ berupa demo dan praktek langsung berbagai macam barang produksi aksesoris (bando, jepit rambut, kalung, anting, gelang), dimana penjelasan langsung dari tim pelaksana pelatihan.

\section{Rancangan Pelaksanaan Program}

Kegiatan Pengabdian Kepada Masyarakat dilaksanakan selama 3 bulan. Tempat kegiatan dilakukan di Gedung Serbaguna Rukun Warga 10 Kelurahan Cipinang Besar Utara Jakarta Timur. Adapun Jadwal kegiatan sebagai berikut:

\begin{tabular}{|c|c|c|c|c|}
\hline \multirow[t]{2}{*}{ No } & \multirow[t]{2}{*}{ Kegiatan } & \multicolumn{3}{|c|}{ Bulan ke- } \\
\hline & & 1 & 2 & 3 \\
\hline 1. & $\begin{array}{l}\text { Pembuatan } \\
\text { proposal }\end{array}$ & & & \\
\hline 2. & $\begin{array}{l}\text { Pendataan } \\
\text { peserta }\end{array}$ & & & \\
\hline 4. & Persiapan & & & \\
\hline 5. & Pelaksanaan & & & \\
\hline 6. & $\begin{array}{l}\text { Pembuatan } \\
\text { Laporan }\end{array}$ & & & \\
\hline
\end{tabular}




\section{E. Perincian Prosedur Kerja}

1. Teknik Pembuatan

Langkah umum membuat produk adalah :

a. Membersihkan botol;

b. Membuat motif dari botol, dengan menggunakan beberapa teknik, yaitu teknik gunting, teknik sticker, teknik gambar, teknik panas, teknik panggan;

c. Diselesaikan sesuai dengan jenis produknya sebagai berikut.

\section{Kalung}

\section{Alat :}

1. Gunting

2. Lem UHU

3. Paku pembolong

4. Tang Kecil

5. Spidol

\section{Bahan :}

1. Botol Plastik Aneka Warna

2. Rantai

3. Ring aneka ukuran

\section{Cara Membuat :}

1. Siapkan alat dan bahan yang akan di gunakan.

2. Buat pola hiasan pada lembaran botol plastik sesuai desain yang di inginkan.

3. Gunting sesuai pola tersebut.

4. Lakukan hal yang sama untuk beberapa bagian

5. Sisihkan semua pola yang telah di gunting.

6. Siapkan potongan botol plastik, lubangi sisinya dengan paku pembolong

7. Lakukan pelubangan potongan botol plastic sesuai desain yang di inginkan.

8. Sisihkan semua potongan yang telah di lubangi.

9. Ambil rantai lalu ambil ring ukuran sedang dan masukan pada ke dua ujung rantai

10. Ambil potongan botol plastic lalu masukan bagian yang berlubang tersebut dengan ring ukuran kecil (lakukan pada semua again botol plastic yang berlubang).

11. Untuk menyatukan potongan botol satu dengan yang lainya gunakan ring ukuran sedang.

12. Lakukan langkah terakhir sesuai desain yang telah di tentukan.
Anting

Alat :

1. Gunting

2. Tang Kecil

3. Spidol

Bahan :

1. Botol Plastik Aneka Warna

2. Kokot Anting

3. Ring aneka ukuran

4. Rantai

5. Kawat

6. Mute Aneka Warna

\section{Cara Membuat :}

1. Siapkan alat dan bahan yang akan di gunakan.

2. Buat pola hiasan pada lembaran botol plastik sesuai desain yang di inginkan.

3. Gunting sesuai pola tersebut.

4. Lakukan hal yang sama untuk beberapa bagian

5. Sisihkan semua pola yang telah di gunting.

6. Siapkan potongan botol plastic.

7. Lubangi bagian atas potongan plastik lakukan pada setiap bagian.

8. Ambil mute dan kawat, masukan kawat kedalam mute, buat lilitan kawatspiral pada mute.

9. Ambil kokot anting, masukan ring ukuran besar lalu sambungkan dengan ring ukuran kecil.

10. Selanjutnya sambung dengan ring kecil lagi, lalu sambungkan dengan ring ukuran sedang, (lakukan sesuai desain).

11. Pada langkah terakhir masukan potongan plastic yang telah di lubangi pada ring terakhir.

12. Lalu sambungkan mute yang telah di lilitkan kawat spiral pada ring yang telah di tentukan sesuai desain.

Lakukan langkah tersebut pada anting yang satunya.

\section{Gelang}

Alat :

1. Gunting

2. Tang Kecil

3. Spidol 


\section{Bahan :}
1. Botol Plastik Aneka Warna
2. Penjepit pita
3. Ring aneka ukuran
4. Lobster (pengait)

\section{Cara Membuat :}

1. Siapkan alat dan bahan yang akan di gunakan.

2. Buat pola hiasan pada lembaran botol plastik sesuai desain yang di inginkan.

3. Gunting sesuai pola tersebut.

4. Lakukan hal yang sama untuk beberapa bagian

5. Sisihkan semua pola yang telah di gunting.

6. Siapkan potongan botol plastik, satukan ujung lembaran potongan botol plastic dengan penjepit pita.

7. Masukan beberapa mute mute sesuai keinginan pada potongan botol plastic.

8. Lakukan langkah tersebut sesuai desain yang telah di tentukan.

9. Apabila sudah selesai, satukan ujung lembaran botol plastic dengan penjepit pita.

10. Setelah kedua sisi gelang telah selesai masukan ring kecil pada penjepit pita (lakukan di kedua sisi gelang).

11. Lalu setelah itu kaitkan pengait atau lobster pada salah satu sisi gelang dan sisi satunya lagi kaitkan dengan ring ukuran sedang.

\section{Bando}

Alat :

1. Gunting

2. Lem UHU

3. Paku pembolong

4. Tang Kecil

5. Spidol

\section{Bahan :}

1. Botol Plastik Aneka Warna

2. Bando Warna- Warni

3. Pita Aneka Motif Dan Warna

4. Kancing Warna Warni

5. Kawat Nyamuk Plastik

6. Kain flanel

\section{Cara Membuat :}

1. Siapkan alat dan bahan yang akan di gunakan.

2. Buat pola hiasan pada lembaran botol plastik sesuai desain yang di inginkan.

3. Gunting sesuai pola tersebut.

4. Lakukan hal yang sama untuk beberapa bagian

5. Buat pola serta gunting kawat nyamuk plastik sesuai dengan pola yang di inginkan.

6. Sisihkan semua pola yang telah di gunting.

7. Ambil bando plastic, rekatkan pita pada bando plastic menggunakan lem uhu.

8. Tandai bagian bando yang akan di hias dengan pola yang telah di buat sebelumnya.

9. Tempelkan potongan kecil kain flannel diatas bando yang telah di hias pitasebelumnya.

10. Ambil lem uhu tempelkan di atas potongan kain flanel lalu mulai menempel pola botol plastic yang telah di gunting perbagian satu persatu sesuai dengan desain yang di inginkan.

\section{Jepit Rambut}

Alat :
1. Gunting
2. Spidol
3. Lem UHU

\section{Bahan :}

1. Botol Plastik Aneka Warna

2. Jepitan Buaya

3. Kancing Aneka Ukuran dan Warna

4. Kain Flanel

5. Kawat Nyamuk Plastik

\section{Cara Membuat :}

1. Siapkan alat dan bahan yang akan di gunakan.

2. Buat pola hiasan pada lembaran botol plastik sesuai desain yang di inginkan.

3. Gunting sesuai pola tersebut.

4. Lakukan hal yang sama untuk beberapa bagian

5. Sisihkan semua pola yang telah di gunting.

6. Siapkan potongan botol plastic.

7. Potong kain flanel sesuai pola jepitan buaya.

8. Ambil jepitan buaya lalu rekatkan kain flanel menggunakan lem uhu. 
9. Lalu ambil lem uhu dan rekatkan satu persatu bagian potongan botol plastic di atas kain flannel.

10. Lalukan langkah diatas hingga terbentuk pola yang diinginkan.

11. Lalu pada bagian atas rekatkan potongan kawat nyamuk plastic lalu rekatkan juga kancing ukuran sedang dan kecil menggunakan lem uhu.

\section{F. Evaluasi}

Evaluasi kegiatan dilakukan dengan melihat kemajuan peserta selama proses kegiatan. Diakhir kegiatan disediakan 3 hadiah bagi (3) tiga peserta yang berhasil memperoleh nilai tertinggi berdasarkan kelima produk tersebut.

\section{LEMBAR PENILAIAN \\ PRODUK AKSESORIS DARI LIMBAH BOTOL PLASTIK PENGABDIAN PADA MASYARAKAT DI KELURAHAN CIPINANG BESAR}

\begin{tabular}{|c|c|c|c|c|c|c|c|}
\hline \multirow[t]{2}{*}{ NO } & \multirow[t]{2}{*}{ NAMA } & \multirow[t]{2}{*}{ PRODUK } & \multicolumn{3}{|c|}{ PENILAIAN } & \multirow[t]{2}{*}{ TOTAL } & \multirow[t]{2}{*}{ PERINGKAT } \\
\hline & & & KREATIVITAS & ESTETIKA & KERAPIHAN & & \\
\hline & & 1. BANDO & & & & & \\
\hline \multicolumn{8}{|l|}{1.} \\
\hline & & 2. KALUNG & & & & & \\
\hline \multicolumn{8}{|l|}{1.} \\
\hline & & 3. GELANG & & & & & \\
\hline \multicolumn{8}{|l|}{1.} \\
\hline & & 4. ANTING & & & & & \\
\hline \multicolumn{8}{|l|}{1.} \\
\hline & & 5. JEPITAN & & & & & \\
\hline 1. & & & & & & & \\
\hline
\end{tabular}

Evaluasi kegiatan dilakukan dengan melakukan penilaian terhadap produk yang terlah dibuat. Pertama, penilaian kreativitas. Kreativitas lebih ditekankan pada keterbatasan pemanfaatan limbah dan bahan pendukung yang digunakan sebagai model produk aksesoris yang dibuat

Kedua, estetika. Estetika adalah satu ilmu yang mempelajari segala sesuatu yang berkaitan dengan keindahan, mempelajari semua aspek dari apa yang kita sebut keindahan. Estetika lebih dilihat pada keindahaan produk aksesoris yang dihasilkan.

Ketiga, kerapihan. Kerapihan dilihat dari hasil produk khususnya terhadap hasil pemotongan limbah botol.

\section{HASIL DAN PEMBAHASAN}

Kegiatan dihadiri oleh ibu-ibu PKK RW.010. Kelurahan Cipinang Besar Utara, Sekretaris, dan wakil dari Lembaga Pengabdian Masyarakat UNJ (Ibu Marni Lestari). Adapun acara kegiatan dilaksanakan selama 2 hari sebagai berikut.

Pertama, pembukaan oleh Sekretaris RW.010 kemudian dilanjutkan laporan dari Ketua Kegiatan sekaligus penjelasan pelatihan dan pembagian bahan praktek dan contoh model produk. Kedua, kegiatan pelatihan. Berikut hasil dokumentasi kegiatan

Hasil kegiatan berupa produk aksesoris dengan 1 (satu) model untuk bando, anting, jepit rambut, gelang, dan kalung. Model yang dipilih adalah model sederhana yang lebih mudah dibuat.

\section{KESIMPULAN DAN SARAN}

Kegiatan ini menghasilkan beberapa produk aksesoris seperti bando, kalung, gelang, anting, serta jepit rambut. Produk ini merupakan hasil kreativitas ibu-ibu PKK RW. 010 Kelurahan Cipinang Besar Utara. Latihan ini diperlukan, untuk menghasilkan produk yang menghasilkan nilai ekonomis lebih baik. 


\begin{abstract}
Kegiatan ini telah memberikan pengetahuan dan keterampilan tentang pembuatan produk dengan memanfaatkan limbah botol plastik menjadi produk yang lebih berguna. Dengan demikian, kegiatan ini akan dapat mengurangi volume sampah sekaligus meningkatkan penghasilan keluarga.

Penghasilan keluarga meningkat maka keluarga dapat dikatakan sejahtera serta otomatis akan meningkatkan kesejahteraan negara. Keluarga yang menginginkan penghasilan keluarganya meningkat akan memilih kegiatan wirausaha. Dukungan dari lembaga pendidikan sangat diperlukan agar kegiatan wirausaha berkesinambungan khususnya ketrampilan dan teknologi tepat guna dalam memanfaatkan limbah botol plastik.
\end{abstract}

DAFTAR PUSTAKA

[1] ----Berita 86. 2010. Aneka Souvenir Cantik Dari Limbah Botol Air Mineral.
Diunduh dari http://www.berita86. com/2010/03/aneka-souvenir-cantikdari-limbah-botol.html

[2] -----Milchop. 2014. Diunduh dari http://www.milchop.com/info/fashiontrends-and-styles/apa-itu-eco-fashion/.

[3] Lupiyoadi, Rambat. 2004. Entrepreneurship from mindset to strategy, Edisi Kedua. Penerbit Fakultas Ekonomi Universitas Indonesia. Jakarta.

[4] Sukardi, Iman S. 1991. Intervensi terencana faktor-faktor lingkungan terhadap pembentukan sifat-sifat entrepreneur. Disertasi Fakultas Pascasarjana Universitas Indonesia. Jakarta.

[5] Wikipedia. 2010. Keluarga. Tersedia pada http://id.wikipedia.org/ wiki/Keluarga. Diakses pada 27 maret 2014

[6] W.J.S. Poewardaminta, Kamus Besar Bahasa Indonesia Edisi 2. Jakarta: Departemen Pendidikan Indonesia, 2008. 